\title{
Energy Coupling in Methylosinus trichosporium
}

\author{
By G. M. TONGE, $†$ J. W. DROZD† AND I. J. HIGGINS* \\ * Biological Laboratory, University of Kent, Canterbury CT2 $7 \mathrm{NJ}$ \\ and \\ † Biosciences Laboratory, Shell Research Ltd, Sittingbourne, Kent ME9 8 AG
}

(Received 29 October 1976)

\section{INTRODUCTION}

Methane-utilizing bacteria are of potential value for production of single-cell protein and the efficiency with which they convert methane to biomass is therefore of practical as well as theoretical interest. Several reports of cell-yield determinations have recently been collated (Barnes et al., 1977), but there is some variation in the values obtained. Recent studies with several methylctrophs (Davey \& Mitton, 1973; Tonge et al., 1974; Anthony, 1975a; Widdowson \& Anthony, 1975) have led to schemes being proposed for their electron transport and energy transducing systems (Tonge et al., 1975; Higgins, Knowles \& Tonge, 1977). Theoretical analyses of the relationships between cell-yield data, sites of ATP synthesis and $\mathrm{P} / \mathrm{O}$ ratios have also been published (Van Dijken \& Harder, I975; Barnes et al., I977). However, there are no direct experimental data concerning either the sites of ATP synthesis or the $\mathrm{P} / \mathrm{O}$ ratios associated with substrate oxidation in these bacteria.

The chemiosmotic theory of oxidative phosphorylation (Mitchell, I $966 a, b$ ) postulates that a transmembrane proton gradient is generated as a result of electron flow down the respiratory chain and that this gradient can drive ATP synthesis such that I mol ATP is synthesized per 2 g-equiv. $\mathrm{H}^{+}$translocated. Therefore, the $\mathrm{P} / \mathrm{O}$ ratio can be calculated from measurements of the $\rightarrow \mathrm{H}^{+} / \mathrm{O}$ ratios (g-equiv. $\mathrm{H}^{+}$translocated per g-atom $\mathrm{O}$ consumed). Recently such ratios have been estimated for a range of heterotrophic bacteria (Jones et al., 1975), the chemoautotrophs, Hydrogenomonas eutropha (Beatrice \& Chappell, 1974), Thiobacillus neapolitanus (Drozd, 1974) and Nitrosomonas europeae (Drozd, 1976), and indirectly in Nitrobacter winogradskyi (Cobley, 1976). In all these studies the $\rightarrow \mathrm{H}^{+} / \mathrm{O}$ ratios generally indicated a $\mathrm{P} / \mathrm{O}$ ratio which was in good agreement with that predicted from previous work (Peck, I968; Suzuki, 1974). We describe here similar studies with the obligate methylotroph Methylosinus trichosporium.

\section{METHODS}

Micro-organism, source, maintenance and culture. Methylosinus trichosporium ов $3 \mathrm{~b}$ was a gift from Professor R. Whittenbury, Department of Biological Sciences, University of Warwick, and was maintained and grown on methane in continuous culture as described previously (Tonge, Harrison \& Higgins, 1977).

Preparation of washed bacterial suspensions. Organisms were harvested $(6000 \mathrm{~g}, 30 \mathrm{~min}$, $4{ }^{\circ} \mathrm{C}$ ), washed with Tris/ $\mathrm{HCl}$ buffer (I $\mathrm{mM}, \mathrm{pH} 7 \cdot \mathrm{I}$ ) containing $\mathrm{KCl}$ (I40 mM) and resuspended in the same buffer to a density of 5 to Io $\mathrm{mg}^{\mathrm{dry}} \mathrm{wt} \mathrm{ml}^{-1}$. For subsequent use, organisms were usually starved by incubating suspensions for 2 to $6 \mathrm{~h}$ at $30^{\circ} \mathrm{C}$ on a rotary shaker at 210 rev. $\min ^{-1}$. 
Determination of $\rightarrow H^{+} / O$ ratios. The ratios were measured as described by Drozd (1976), using the following substrate concentrations: methane, $30 \mu \mathrm{M}$; methanol, 0.5 to $2 \mathrm{mM}$; formaldehyde, $2 \mathrm{mM}$; sodium formate, 0.5 to $10 \mathrm{mM}$; ascorbate (I.5 mM) $/ N, N, N^{\prime}, N^{\prime}$ tetramethyl-p-phenylenediamine (TMPD), 4.0 mM. Incubation mixtures contained carbonate dehydratase (EC. 4.2.I.I; $30 \mu \mathrm{g} \mathrm{ml}^{-1}$ ), and potassium thiocyanate (I50 mM) was added at least 10 min before making measurements to neutralize any electrical charge across the membrane and to maximize the $\mathrm{pH}$ difference. The scale was calibrated by adding nitrogen-sparged o.01 M-KOH.

Determination of respiration rates. Respiration rates were measured at $30^{\circ} \mathrm{C}$ in a Rank oxygen electrode (Rank Bros, Bottisham, Cambridgeshire) using substrate concentrations as described for the determination of $\rightarrow \mathrm{H}^{+} / \mathrm{O}$ ratios. Incubation mixtures (total volume $3 \mathrm{ml}$ ) contained, in addition to substrate: Tris/ $\mathrm{HCl}$ buffer ( $\mathrm{I} \mathrm{mM}, \mathrm{pH} 7 \cdot \mathrm{I}$ ); $\mathrm{KCl}$ (I $40 \mathrm{mM}$ ); and organism suspension ( 15 to $30 \mathrm{mg}$ dry wt).

Chemicals. Methane was purchased from British Oxygen Co., methanol, paraformaldehyde and formate from BDH. Formaldehyde was prepared from paraformaldehyde as described by Strøm, Ferenci \& Quayle (1974). Carbonyl cyanide $m$-chlorophenylhydrazone and carbonate dehydratase were obtained from Sigma.

\section{RESULTS}

Typical small acidifications of the external medium (proton pulses) were observed when air-saturated potassium chloride (140 mM) was added to suspensions of $M$. trichosporium incubated with methane, ascorbate/TMPD or known intermediates in methane oxidation. The magnitude of these pulses was independent of the $\mathrm{pH}$ of the Tris/ $\mathrm{HCl}$ buffer over the $\mathrm{pH}$ range 6.6 to 7.8 and the $t_{\frac{1}{2}}$ of decay of the pulses was in the range 40 to $80 \mathrm{~s}$. The $\rightarrow \mathrm{H}^{+} / \mathrm{O}$ ratios obtained using starved suspensions of $M$. trichosporium are shown in Table $\mathrm{I}$. Separate determinations using an oxygen electrode (see Methods) showed that these preparations had negligible endogenous respiration rates but, with the substrates tested in Table 1 , values of 29 to $37 \mu \mathrm{mol} \mathrm{O}_{2}$ consumed (g dry wt) ${ }^{-1} \mathrm{~min}^{-1}$ were recorded. The use of unstarved organisms did not result in appreciable deviation from these $\rightarrow \mathrm{H}^{+} / \mathrm{O}$ ratios and the presence of carbonate dehydratase in the assay obviated any need to correct for proton production in the formate oxidase reaction (Garland, Downie \& Haddock, 1975). A wide range of sodium formate concentrations was used to ensure that the formate dehydrogenase was saturated with substrate. The rates of decay of pulses were unaltered by sodium formate. There was, therefore, no evidence for any rapid $\mathrm{Na}^{+}: \mathrm{H}^{+}$antiport mechanisms (West \& Mitchell, 1974) which might have interfered with extrapolation of pulse heights.

The addition of ethanolic carbonyl cyanide $m$-chlorophenylhydrazone uncoupling agent ( $5 \mu \mathrm{M}$ final concn) at pulse maxima caused their rapid collapse and thereafter it was not possible to evoke pulses by further additions of air-saturated $\mathrm{KCl}$ (I40 $\mathrm{mM}$ ).

\section{DISCUSSION}

The effects of carbonyl cyanide $m$-chlorophenylhydrazone are consistent with predictions of the chemiosmotic hypothesis since this is an uncoupling agent that would increase proton conduction across membranes. Thus these results suggest that the minute $\mathrm{pH}$ changes measured are genuine reflexions of metabolically-linked proton extrusion. A rapid uptake of hydroxyl ions by the bacteria would also explain the results, but in terms of the chemiosmotic theory this would not satisfy the postulated mechanisms for proton-driven ATP 
Table I. $\rightarrow H^{+} / O$ ratios for washed suspensions of Methylosinus trichosporium

Ratios were determined using starved organisms as described in Methods. Average values are quoted together with the standard error of the mean and the number of determinations (in parentheses). Measurements were made on four different batches of organisms for each substrate.

$\begin{array}{lc}\text { Added substrate } & \rightarrow \mathrm{H}^{+} / \mathrm{O} \\ \text { Methane } & \mathrm{I} \cdot 9 \pm 0.13(4) \\ \text { Methanol } & \mathrm{I} \cdot 8 \pm 0 . \mathrm{I} 2(5) \\ \text { Formaldehyde } & \mathrm{I} \cdot 9 \pm 0.05(7) \\ \text { Formate } & \mathrm{I} \cdot 7 \pm 0.15(9) \\ \text { Ascorbate/TMPD } & \mathrm{I} \cdot 5 \pm 0.05(5)\end{array}$

synthesis. The $\rightarrow \mathrm{H}^{+} / \mathrm{O}$ ratios suggest a probable $\mathrm{P} / \mathrm{O}$ ratio of $\mathrm{I}$ for all substrates tested on the assumption that $\mathrm{I}$ mol ATP is synthesized per 2 g-equiv. $\mathrm{H}^{+}$translocated. The value for ascorbate/TMPD is entirely consistent with entry of electrons into a conventional respiratory chain at the level of cytochrome $c$. Methanol and formaldehyde oxidation in M. trichosporium and other methylotrophs is closely linked to cytochrome $c$ reduction (Tonge et al., 1975; Higgins et al., 1977; Anthony, 1975b; Widdowson \& Anthony, 1975), and therefore a P/O ratio of I would be expected for the activity of proton-translocating loop 3 (Mitchell, 1970). These results are similar to those obtained for thiosulphate oxidation in Thiobacillus neapolitanus (Drozd, 1974) and hydroxylamine oxidation in Nitrosomonas europeae (Drozd, 1976), where substrate oxidation is closely linked to cytochrome $c$ reduction (Aleem \& Lees, 1963; Aleem, 1970; Suzuki, 1974).

A P/O ratio of $\mathrm{I}$ for formate is unexpected since its oxidation is known to be NADHlinked (Quayle, 1972). This suggests two of the three proton translocating loops normally associated with NADH oxidation are missing or that NADH oxidation via a conventional electron transport pathway does not occur. There is some evidence for the latter hypothesis (Higgins et al., 1977; Tonge, Drozd \& Higgins, 1976; Tonge et al., 1977). During oxidation of methane to carbon dioxide the only source of NADH is the formate dehydrogenase reaction (Quayle, 1972). Some of this NADH is required for general biosynthetic reactions and in $M$. trichosporium (a serine pathway organism) a large proportion is required to fix carbon dioxide. Therefore, only a small amount of NADH is available for energy transduction and there may have been little selective advantage during evolution in developing more than one coupling site. During the oxidation of methane, oxygen is consumed in an oxygenase reaction (Tonge et al., 1977) and therefore the apparent $\mathrm{P} / \mathrm{O}$ ratio of $\mathrm{I}$ for methane suggests a true $\mathrm{P} / \mathrm{O}$ ratio of 2 . However, it is possible that the $\rightarrow \mathrm{H}^{+} / \mathrm{O}$ ratio is an overestimate due to the difficulty of measuring proton pulses using a limited quantity of gaseous substrate whose further oxidation can lead indirectly to endogenous cytochrome $c$ reduction. A scheme for electron supply to the methane monooxygenase of $M$. trichosporium, in which electrons derived from the oxidation of methanol and formaldehyde are recycled into the monooxygenase reaction, has been proposed (Tonge et al., 1975, Higgins et al., 1977). It is possible that there is a further coupling site available during this recycling process but this would not be necessary to account for observed growth yields on methane or methanol which suggest that as much ATP is probably produced during the oxidation of I mol methane as from the oxidation of $\mathrm{I}$ mol methanol.

We would like to express our gratitude to Dr D. E. F. Harrison for useful suggestions. This work was supported by grants to I.J.H. from the Science Research Council and the Shell Grants Committee. G.M.T. held an S.R.C. CASE award. 


\section{REFERENCES}

Aleem, M. I. H. (1970). Oxidation of inorganic nitrogen compounds. Annual Review of Plant Physiology 21, 67-90.

Aleem, M. I. H. \& Lees, H. (I963). Autotrophic enzymic systems. I. Electron transport systems concerned with hydroxylamine oxidation in Nitrosomonas. Canadian Journal of Biochemistry and Physiology 4r, $763-778$.

Anthony, C. (1975a). The biochemistry of methylotrophic micro-organisms. Science Progress, Oxford 62, $167-206$.

ANTHONY, C. (I975 b). The microbial metabolism of $\mathrm{C}_{1}$ compounds: the cytochromes of Pseudomonas AMI Biochemical Journal r46, 289-298.

Barnes, L. J., Drozd, J. W., Harrison, D. E. F. \& Hamer, G. (1977). Process considerations and techniques specific to protein production from natural gas. In Microbial Production and Utilisation of Gases $\left(\mathrm{H}_{2}, \mathrm{CH}_{4}, \mathrm{CO}\right)$. Edited by H. G. Schlegel. Göttingen: Goltze-Druck (in the Press).

Beatrice, M. C. \& Chappell, J. B. (I974). Respiration-driven proton translocation in Hydrogenomonas eutropha HI6. Biochemical Society Transactions 2, I 5 I-1 53.

CoBley, J. G. (1976). Reduction of cytochromes by nitrite in electron-transport particles from Nitrobacter winogradskyi. Biochemical Journal 156, 493-498.

Davey, J. F. \& Mitton, J. R. (I973). Cytochromes of two methane-utilising bacteria. FEBS Letters 37, 335337.

DrozD, J. W. (1974). Respiration-driven proton translocation in Thiobacillus neapolitanus C. FEBS Letters 49, $103-105$.

DrozD, J. W. (1976). Energy coupling and respiration in Nitrosomonas europeae. Archives of Microbiology I Io, 257-262.

Garland, P. B., Downie, A. J. \& Haddock, B. A. (1975). Proton translocation and the respiratory nitrate reductase of Escherichia coli. Biochemical Journal r52, 547-559.

Higgins, I. J., Knowles, C. J. \& Tonge, G. M. (1977). Enzymic mechanisms of methane and methanol oxidation in relation to electron transport systems in methylotrophs: purification and properties of methane oxygenase. In Microbial Production and Utilisation of Gases $\left(\mathrm{H}_{2}, \mathrm{CH}_{4}, \mathrm{CO}\right)$. Edited by $\mathrm{H}$. G. Schlegel. Göttingen: Goltze-Druck (in the Press).

Jones, C. W., BRICE, J. M., DownS, A. J. \& DrozD, J. W. (I975). Bacterial respiration-linked proton translocation and its relationship to respiratory chain composition. European Journal of Biochemistry 52, 265271 .

Mrtchell, P. (1966a). Chemiosmotic Coupling in Oxidative and Photosynthetic Phosphorylation. Bodmin, Cornwall: Glynn Research Ltd.

Mitchell, P. (1966b). Chemiosmotic coupling in oxidative and photosynthetic phosphorylation. Biological Reviews 4I, 445-502.

MitChell, P. (1970). Membranes of cells and organelles. Symposia of the Society for General Microbiology 20, I 2 I-I 66 .

PeCK, H. D. (1968). Energy coupling mechanisms in chemolithotrophic bacteria. Annual Review of Microbiology 22, 489-51 8 .

QUAYLE, J. R. (1972). The metabolism of one-carbon compounds by microorganisms. Advances in Microbial Physiology 7, 1 19-203.

STrøm, T., Ferenci, T. \& QuaYle, J. R. (I974). The carbon assimilation pathways of Methylococcus capsulatus, Pseudomonas methanica and Methylosinus trichosporium (OB 3b) during growth on methane. Biochemical Journal r44, 465-476.

SuzUkI, I. (I 974). Mechanisms of inorganic oxidation and energy coupling. Annual Review of Microbiology 28, 85-IOI.

Tonge, G. M., Knowles, C. J., Harrison, D. E. F. \& Higgins, I. J. (I974). Metabolism of one-carbon compounds: cytochromes of methane and methanol-utilising bacteria. FEBS Letters 44, 106-1 10.

Tonge, G. M., HArrison, D. E. F., Knowles, C. J. \& Higgins, I. J. (I975). Properties and partial purification of the methane-oxidizing enzyme system from Methylosinus trichosporium. FEBS Letters 58, 293299.

Tonge, G. M., Drozd, J. W. \& Higgins, I. J. (1976). Respiration and energy coupling in Methylosinus trichosporium. Proceedings of the Society for General Microbiology 3, 179.

Tonge, G. M., Harrison, D. E. F. \& Higgins, I. J. (1977). Purification and properties of the methane mono-oxygenase enzyme system from Methylosinus trichosporium ов $3 \mathrm{~b}$. Biochemical Journal (in the Press).

VAN Dijken, J. P. \& Harder, W. (1975). Growth yields of micro-organisms on methanol and methane. A theoretical study. Biotechnology and Bioengineering 17, $15-30$.

West, I. C. \& Mrtchell, P. (1974). Proton/sodium ion antiport in Escherichia coli. Biochemical Journal 144, $87-90$.

Widdowson, D. \& Anthony, C. (I 975). The microbial metabolism of $\mathrm{C}_{1}$ compounds. The electron transport chain of Pseudomonas AMI. Biochemical Journal 152, 349-356. 